\title{
Organic barley producers' desired qualities for crop improvement
}

\author{
Brian P. Baker (D) • Brigid M. Meints • Patrick M. Hayes
}

Received: 16 April 2020 / Accepted: 23 April 2020 /Published online: 13May 2020

(C) The Author(s) 2020

\begin{abstract}
Barley fits well into many different organic farming systems. It can be grown as either a winter or spring annual crop in many temperate regions. Barley can be used for food, malting, or animal feed, providing growers with diverse marketing opportunities. Despite its advantages, many organic farmers in the USA have not adopted barley as a regular crop in their rotation. Researchers surveyed organic barley producers to discover what they considered to be the main obstacles to growing barley. The primary obstacles identified were limited markets and price. Breeding and development of high-quality barley suitable for organic systems and specialty markets may be a way to expand markets and secure a better price. Farmers identified yield as the most important agronomic trait of interest, but other traits such as nutritional quality were also highly ranked. Naked (hull-less) barley bred for multi-use quality is a possible alternative that allows organic farmers to sell into multiple markets. Most respondents expressed interest in the development of such varieties suitable for organic farming conditions. The researchers conducted follow-up interviews to obtain detailed information on how barley is used in organic farming systems, production practices, costs of production, and what traits farmers would like to see breeders focus on.
\end{abstract}

Keywords Barley · Organic farming systems · Surveys · Plant breeding Production costs

B. P. Baker $(\bowtie) \cdot$ B. M. Meints • P. M. Hayes

Oregon State University Department of Crop and Soil Science,

Corvallis, OR 97333, USA

e-mail: bakebria@oregonstate.edu

\section{Introduction}

Small grains play an important role in many organic farming systems (Lampkin 1990; Wijnands 1999; Lazor 2013). They can be added into crop rotations to help break pest, weed, and disease cycles, and to enhance the biodiversity of the system (Mohler and Johnson 2009). Because they are relatively low-cost, low-input, and low-risk compared with other organic crops, small grains can be extremely beneficial to growers (Wiersma et al. 2010). Small grains help to promote soil aggregation more than many cash crops, which contributes to the overall soil health of the system (Drinkwater 1999). In regions where grains can successfully overwinter, fall-planted grains can fit into production windows not available to other crops. Additionally, winter small grains can help suppress weeds in subsequent crops (Teasdale et al. 2007; Anderson 2010; Ryan et al. 2011; Baker and Mohler 2014). Disease and insect pests can be managed effectively by choosing resistant varieties and using cultural control methods (Wiersma et al. 2010).

Barley (Hordeum vulgare L.) offers many benefits for organic farming systems. In regions where it is suitable as a winter grain, barley establishes rapidly in the fall and can out-compete annual winter weeds. Because of its quick canopy growth after seeding, barley can be quite competitive against weeds. Many diseases and insects that affect barley are regionally specific, but this pressure can generally be managed effectively using integrated pest management strategies. However, it is important to note that most currently available varieties 
have been selected for conventional growing conditions and many may not always be the best suited for organic farming conditions; breeding new varieties under organic conditions can help remedy this. Barley offers some advantages over other small grains: it requires less nitrogen than wheat and matures more quickly than other small grains, which allows subsequent crops to be planted earlier (Wiersma et al. 2010).

Because it can be malted for brewing and distilling, eaten as a food grain, and fed to livestock, barley provides diverse marketing options. It can also be intercropped with legumes, which gives producers the option to till it in as a green manure cover crop, harvest before maturity as a green chop fed to livestock, or grow to maturity to market as a mixed feed grain, depending on soil needs and market conditions.

Despite its benefits, many organic farmers have been reluctant to plant barley. New varieties bred for organic systems that meet quality standards to be sold into multiple markets may encourage farmers to add barley to their rotation. In principle, it is possible to breed a naked barley suitable for feed, food, and malting that will perform well in organic systems (Meints and Hayes 2019). In order to inform the breeding process and to understand what qualities, traits, and characteristics organic farmers consider important, the authors designed and implemented a survey and conducted interviews of organic barley producers.

\section{Materials and methods}

The investigators drafted a survey instrument that was pre-tested by one organic barley producer in each of the USDA's Northeast, North Central, and Western regions, as well as by project cooperators at Cornell University and Oregon State University. The final instrument contained 29 questions and was designed to take less than half an hour to complete. The online survey was designed for ease of response as part of a mixed model for data collection that also involved follow-up telephone interviews of a subsample of the population for more in-depth questions. A report that provides more details about the survey preparation and the instrument itself is available online (Baker et al. 2019).

Certified organic barley producers in the USA were identified through the USDA's Organic Integrity Database (USDA / AMS / NOP 2019) and from lists of farmer participants in project events, such as field days. Producers without email addresses were not contacted, which may account for some selection bias in the results. The survey was sent by Qualtrics on February 11, 2019, to 374 email addresses (Qualtrics 2018). Nine of these emails were returned and three were added on February 26 for an adjusted target audience of 368 . Multiple contacts were used to increase the response rate (Dillman et al. 2014).

The survey recipients were sent reminders 15, 32, and 46 days following the initial survey date. The survey was closed on April 1, 2019. A total of 84 full or partial responses were received for a $22.8 \%$ response rate. Of these, 81 of the respondents were active farmers. Two respondents were researchers managing certified organic experiments at research institutes and one was no longer farming. These three responses were excluded from the responses reported below. The data were summarized and charts were produced using Qualtrics and Excel (Microsoft 2016; Qualtrics 2018). Statistical analyses were conducted using SAS University Edition (SAS 2018).

Forty-five survey respondents provided their name and contact information for a follow-up interview. Nineteen organic barley producers were interviewed between November 4, 2019, and January 3, 2020. Interviewees were selected from the pool of volunteers based on geographic diversity, experience with organic farming systems, and operation size, in order to represent different scales. The operations were almost evenly divided between dryland (10) and irrigated (9) farming systems. The main purpose of the interviews was to learn more about the specific obstacles that organic growers face in producing and marketing organic barley and how a breeding program can help address these concerns. The authors designed an interview template that included questions about production practices, costs of production, and specific obstacles to growing high-quality barley.

The interviews were structured in three parts. The first was a narrative description about how barley fits into the interviewee's rotation and farming system. The second involved detailed information on their practices, operations, costs of production, and returns for growing barley. The third part was open-ended and gave the interviewees an opportunity to explain their needs and preferences for barley traits in greater detail. The interviewees were asked in-depth questions that expanded on the questions presented in the survey and provided 
greater detail about production obstacles and how barley breeding could help overcome those challenges.

Interview subjects were asked to provide detailed information about their farming operations. Actual cost data were used when readily available. If the producers could not directly provide costs of production, the data provided about farming operations were used to estimate equipment fuel, operation, and maintenance costs based on the manufacturer's specifications, engineering references, and the most recent edition of relevant $\mathrm{Co}-$ operative Extension data (Downs and Hansen 1998; Grisso et al. 2010; Painter 2011). Capital recovery of machinery and equipment and other allocated overhead expenses not provided by the interviewees were extrapolated from the regional averages provided by the USDA Survey of barley producers following the 2014 Census of Agriculture (USDA / NASS 2019). Interviewees were asked about their land costs, including cash rent, mortgage payments, and property taxes. In cases where actual rents or total cost of land and net of buildings and improvement was not available, rents reported by the most recent USDA survey on land rents by county were used for the opportunity cost of land (USDA NASS 2019). When certification costs per acre were not provided by producers, the budgets used average cost per acre in the state of the operation from 2016 adjusted for inflation (USDA / NASS 2017). Model budget data were verified by the interviewees.

In the absence of specific values provided by the interviewees, the USDA Standards for \#2 generic (non-malting) barley were used as the default values for test weight (USDA / GIPSA 1997). The values were for covered barley in the absence of specific varieties. Higher grades and test weights would result in higher returns per hectare, all other things being equal. The USDA does not have standards for naked varieties. Weight and volume conversion factors for naked barley were obtained from the Canadian Grain Commission (Canadian Grain Commission 2006).

\section{Survey results}

All respondents were certified organic, with $69 \%$ farming their entire operation organically and $31 \%$ split operations. The responses were geographically diverse, with farmers from every USDA region responding. The region with the greatest number of respondents (43) was the Western region, which accounted for almost half the responses. This was followed by the North Central (24) and Northeast regions (14), with only three respondents from the Southern region.

The distribution of income for organic barley producers responding was skewed towards higher income than the national census figures. For example, $75 \%$ of all US farms in 2017 reported farm income of less than $\$ 50,000$ compared with only $19 \%$ of the respondents from this survey (USDA / NASS 2019). The median farm income of the respondents was between $\$ 50,000$ and 249,000. Respondents were disproportionately male, with $95 \%$ compared with $71 \%$ male principal producers reported in the 2017 Census of Agriculture (USDA / NASS 2019). Median age of the farmers was in the 56-65 age bracket, consistent with a median age of 58.6 for farmers in the USA (USDA / NASS 2019). Over half responding had a college, advanced, or professional degree as the highest level of education. The online-only survey may have biased responses towards better educated farmers who are more likely to adopt technologies such as the internet.

Barley is an arable crop and farm sizes of farmers interviewed tended to be larger than average for organic farms, both in their regions and throughout the US. Most farmers managed over 40 ha, with over $30 \%$ managing over 400 ha. Average areas planted and average yields are summarized in Table 1. The respondents' average barley planting was about 89 ha, with an average organic planting of 50 ha. Average yield of organic barley was reported to be $3319 \mathrm{~kg} / \mathrm{ha}$.

The primary use of barley $(61 \%)$ was for feed. Some of the producers indicated that they produce barley for on-farm use as feed, green chop, or haylage and do not market it, but a separate question was not included in the survey to quantify how many barley producers were growing it strictly for their own livestock. Barley marketed for food and malt combined accounted for less than a third of the organic barley produced. The few producers who did not grow barley for feed, food, or malt produced barley for seed. It was not clear in some cases whether producers grew barley with the intention

Table 1 Average barley acreage and yield

\begin{tabular}{lrcr}
\hline & Total & Organic & Naked \\
\hline Average barley planting (ha) & 89 & 50 & 9 \\
Average barley yield (kg/ha) & 3397 & 3319 & 2283 \\
\hline
\end{tabular}

Source: (Baker et al. 2019) 
to sell into the feed market or if they sold it as feed because the higher value food, malting, and seed markets were not available to them.

Organic barley producers were asked about the main obstacles they face in growing barley. Their responses are presented in Fig. 1. Most of the obstacles were related to economic rather than agronomic factors. Limited markets and price were cited as the two main obstacles by nearly half of all respondents. "Not enough land" was given as the main obstacle by $19 \%$ and "doesn't fit in my rotation" was the reason for $10 \%$. All other reasons provided in the survey instrument were viewed as obstacles by less than $10 \%$, including poor yield, weeds, diseases, and insect pests. "Other" reasons given were also more often economic than agronomic. Producers reported lacking the equipment or having insufficient on-farm storage as obstacles.

Approximately $78 \%$ of all producers indicated that they received a premium for organic barley over the conventional (non-organic) commodity price. The average premium was $115 \%$, more than double the conventional price, but individual farms reported a wide range of variation from no premium to a four-fold (400\%) premium over conventional. Segmenting the data into primary markets, those whose crop went mostly or exclusively to feed received an average premium of
$97 \%$. Some of those using barley exclusively for feed were livestock producers who used it on farm, sometimes in the form of haylage not harvested as mature grain. Those who were primarily malt producers received a premium of $131 \%$ on average. Those selling into the food market reported only a $68 \%$ average premium over non-organic. Seed producers reported a consistent premium of $120 \%$ over conventional.

\section{Desired traits}

Producers were also asked about the traits that they found most desirable. Table 2 describes the barley traits most desired by organic barley producers. Yield was the most desirable trait by a wide margin. Nearly half the producers who responded said that yield was their top priority, with $82 \%$ of those responding naming it as one of the top three. The second and third most desirable traits had strong regional preferences.

While yield was clearly the highest priority for producers in all regions, producers expressed significant regional difference in secondary and tertiary priorities. Many western growers - particularly in Californiasaid that varieties that had drought tolerance or a low irrigation requirement were desirable for their systems. In the Western region, $61 \%$ of the producers said that

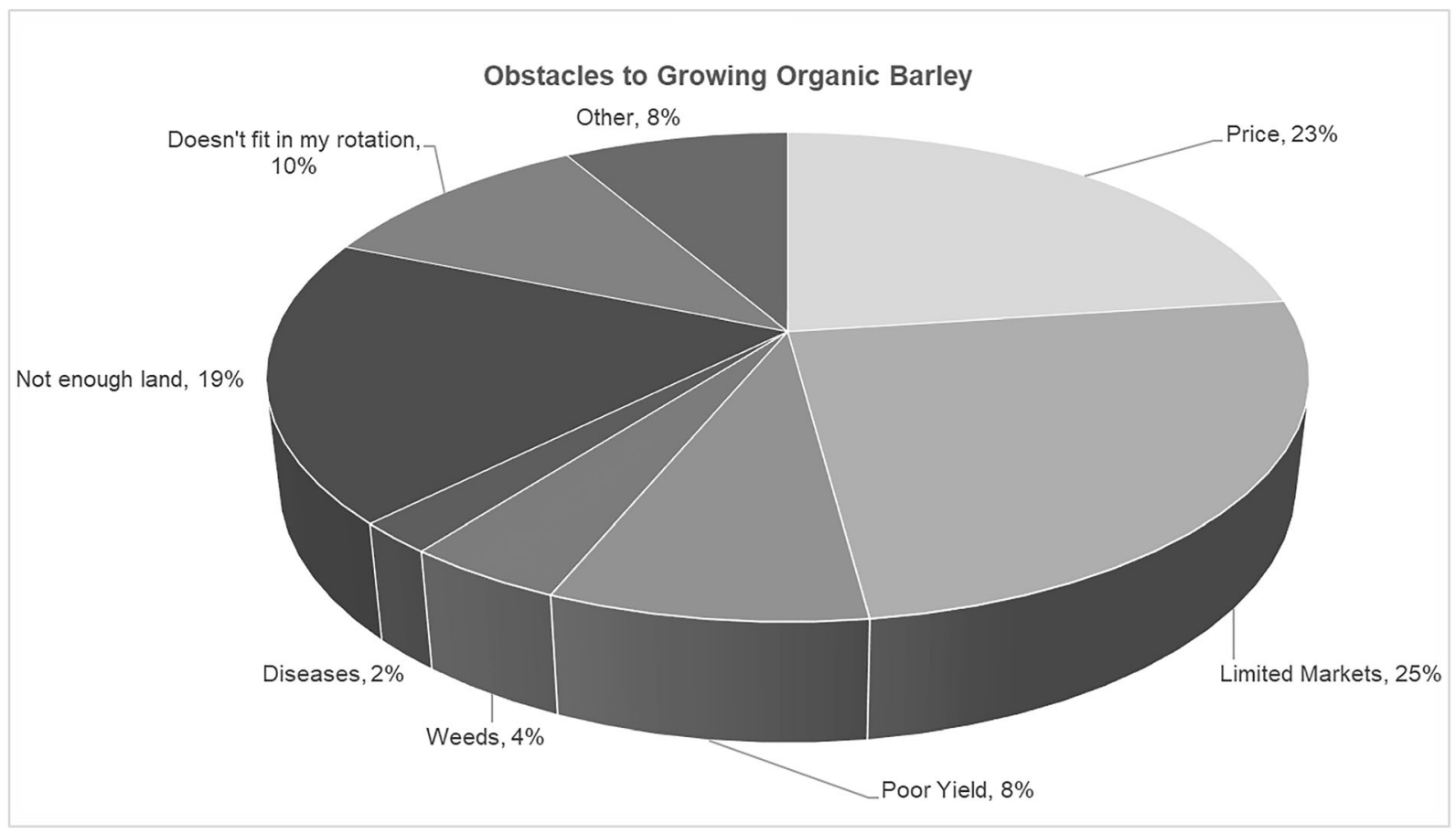

Fig. 1 Obstacles to growing organic barley 
Table 2 Barley traits ranked in importance by organic producers

\begin{tabular}{|c|c|c|c|c|c|}
\hline Weighted rank & Trait & $\% 1 \mathrm{st}$ & $\%$ 2nd & $\% 3 \mathrm{rd}$ & Total \% \\
\hline 1 & Yield & 48 & 24 & 10 & 82 \\
\hline 2 & Drought tolerance & 10 & 7 & 23 & 40 \\
\hline 3 & Winter hardiness & 8 & 21 & 15 & 44 \\
\hline 4 & Competitiveness with weeds & 2 & 19 & 20 & 41 \\
\hline 5 & Disease resistance & 8 & 10 & 10 & 28 \\
\hline 7 & Nutritional quality & 8 & 5 & 3 & 16 \\
\hline 8 & Early germination & 2 & 5 & 10 & 17 \\
\hline
\end{tabular}

Source: (Baker et al. 2019)

drought tolerance was a priority, with $19 \%$ making it a top priority. Water is the first limiting factor in many parts of the region.

On the other hand, barley growers in the North Central and Northeast regions, as well as in some of the colder areas in the Intermountain West such as Montana and Colorado, named winter hardiness as a trait that they wanted to see improved. The need for reliable overwintering varieties was named as the top priority for $29 \%$ of North Central region respondents. A producer in the Appalachian part of the Southern region also cited winter hardiness as a priority second to yield, underscoring barley's importance as an overwintering crop in organic farming systems throughout the USA.

For the Northeast region, the second most important trait after yield was disease resistance, with a third of respondents making it their top priority and over half saying it was in the top three. Winter hardiness came after disease resistance as the third highest priority in the Northeast. None of the producers in the Western region identified winter hardiness as their top priority.

Competitiveness with weeds was either the second or third choice for nearly half the respondents and was selected in all regions. Disease resistance was a high priority for those producers who had problems with specific plant pathogens. These were concentrated in areas of the Northeast and North Central regions, where humidity can create greater disease pressure. Nutritional quality and early germination were also desired by over $10 \%$ of the respondents.

Malting quality, sensory quality, seed coat color, and fiber content were all identified by fewer than $10 \%$ of the producers as a priority. However, these traits might be a priority for livestock producers, maltsters, millers, and other end-users. Several producers in the "Other" category specifically cited lodging as a problem that they hoped to have resolved by barley breeding.

\section{Significant diseases}

Producers were asked to name specific diseases that they identified as problems. The information collected can be used by breeders to select varieties that are resistant to specific diseases. Figure 2 shows the diseases identified by producers. Nearly half $(45 \%)$ said that they did not have any significant diseases that were a problem.

For those that identified significant diseases, there were again distinct regional differences. The most common pathogen nationwide was stripe rust, which was also the most important disease in the North Central region. Producers in the region with the most disease pressure - the Northeast - named powdery mildew as the most important disease. However, this pathogen was not a problem in any other region. The most common disease identified in the Western region was barley yellow dwarf virus.

\section{Naked barley}

This research project is also interested in determining the potential interest organic farmers have in the adopting naked (free threshing) barley varieties. Nearly $25 \%$ of the respondents had grown naked barley in the past three years. However, many indicated that they were unfamiliar with naked barley or had no experience with it. The producers reported smaller average plantings and considerably lower yields for naked barley. The average area planted to naked barley was 9 ha, with an average yield of $2283 \mathrm{~kg} / \mathrm{ha}$. 


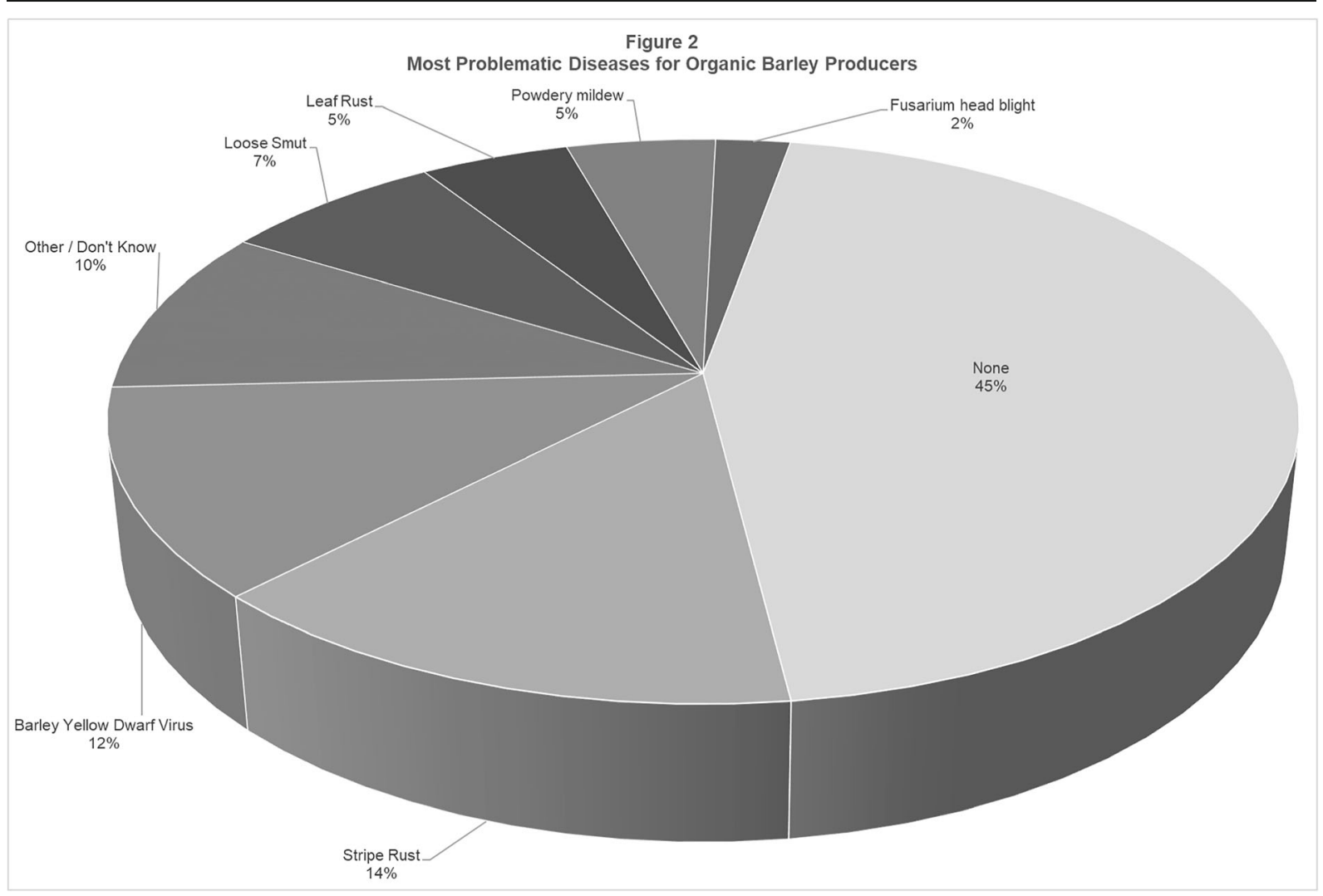

Fig. 2 Most problematic diseases for organic barley producers

The primary obstacle to planting more naked barley named by producers was the lack of seed. This was followed by the lack of winter hardiness, an insufficient premium over covered varieties, and insufficient storage capacity to keep varieties separate. Two producers who had grown naked barley in the past reported that not all the grains free-threshed and that some dehulling was required.

\section{Interviews}

All of the farmers who were interviewed talked about how barley fits within their production system and crop rotation. While there were common elements, each producer had a unique way of integrating barley into their farming system, in terms of place in rotation, cultural practices, variety selection, and end use.

Several producers grew barley for multiple end-uses and were interested in a multi-purpose barley. Barley was the main crop only for farmers who were contract growing for malt houses. For those producers, variety selection was made by contract from the buyer. However, the majority of producers interviewed were primarily selling into the feed market, which reflects the survey results.
Several farmers interviewed talked about the advantages that barley had in terms of land use, labor requirements, and equipment compliment. Barley was often grown as a "catch crop" to make use of nutrients left over from the previous crop's fertility program, particularly when grown as a winter crop. More importantly, several farmers noted that crops following barley had reduced weed pressure and increased yield. According to farmers interviewed, barley is more amenable to no-till systems without herbicides than many other crops in their experience.

Several farmers growing barley were organic dairy producers. Because cattle are ruminants, they can digest barley hulls, and naked barley is not as important for their farming systems. These producers also emphasized the importance of barley for producing high-quality organic straw. By contrast, many of the producers who grow barley as a cash crop do not harvest the straw but will instead till it in for organic matter or plant into the residue, which serves as a mulch. The exceptions were farmers in straw-deficient areas with either high concentrations of dairy farms or near suburban markets.

One of the dairy producers interviewed grows barley as an intercrop with peas. The mixture is harvested 
before the grain matures and is fed as green chop. The mixture is high in total digestible nutrients and he noted that the cattle find it highly palatable. Other dairy producers will harvest the grain and mix it on farm with other components to make a balanced ration.

The interview responses expanded on the survey results, particularly with respect to variety selection. Several talked about the uncertainty presented by climate change, particularly with changing precipitation patterns and timing of planting. Climate change was also thought by some respondents to be responsible for increasing disease pressure. The interviews took place after a particularly wet season, and at least two producers reported partial or complete crop failures. Rains before harvest resulted in crops that were too wet to satisfactorily harvest.

Barley-like wheat in the USA - has low operating costs, high capital costs, and tends to be a low-margin or break-even crop. However, when overhead costs were factored in, the net margin was slightly negative given the relatively high capital investment costs. Organic wheat is similarly a low-margin crop when compared with maize and soybeans (McBride et al. 2015). Cost and return data are summarized in Table 3. However, there were great regional differences in cost of production as well as return per acre. Irrigated farms had higher costs of production, but also higher returns and, based on the interviews, less risk of crop failure in a dry year.

The costs and returns in Table 3 reflect no gross value for farms that harvested barley as green chop instead of grain or reported crop failures. For those producers who marketed their 2019 harvest, the gross margin net of operating costs reported by interviewees for food barley was US\$1159/ha, for malting barley was US\$954/ha, US $\$ 810 /$ ha for feed, and US $\$ 488 /$ ha for barley grown for seed. The low margin for seed reflects the relatively high labor costs and the low net yield from having to reject barley not meeting quality specifications during a wet year.

\section{Discussion and conclusions}

The organic producers surveyed and interviewed view barley as a valuable crop in their rotation, even if it is not always a profitable one. Economic rather than agronomic factors were considered the biggest barriers to the expanded production of barley. However, yield was by far the most important agronomic trait identified by growers, followed by disease resistance and competitiveness with weeds. Organic producers said that they would grow more barley if the price was higher and the profit margin was greater.

The current shortage of organic feed in the USA is one driver of demand. While the feed market is the easiest to access in terms of available marketing and processing infrastructure, and has the lowest quality requirements, it offers a relatively low return. While organic farmers receive a premium over conventional, the premium is not always enough to cover their lower yields and higher unit costs of production. Farmers that were interviewed indicated that food and malt processors were not paying a premium that justified the additional costs of growing for those markets compared with feed. Organic barley grown for malt or food is almost always contracted in advance rather than planted on speculation. On the other hand, there is a ready market for barley as feed, even in the case where it was grown as food or malting barley and does not meet quality specifications. The expansion of the organic malting and food barley markets can be served by the development of varieties with qualities better suited for organic farming conditions. The farmers interviewed indicated that to grow for these higher value markets, they would need to receive a premium over the organic feed price.

Most farmers surveyed and interviewed were supportive of the development of multi-use naked barley varieties. Farmers interviewed demonstrated that barley can play several different roles in organic farming

Table 3 Organic barley costs and returns

\begin{tabular}{lccc}
\hline & Dryland (US\$/ha) & Irrigated (US\$/ha) & All (US\$/ha) \\
\hline Gross value & 1162 & 1511 & 1336 \\
Operating costs & 339 & 538 & 469 \\
Allocated overhead & 311 & 416 & 364 \\
Value net of operating costs & 823 & 973 & 867 \\
Value net of total costs & 512 & 557 & 503 \\
\hline
\end{tabular}


systems. They indicated that they are interested in a barley that can be sold into a variety of markets.

Funding information The project was funded by the US Department of Agriculture National Institute of Food and Agriculture Organic Agriculture Research and Extension Initiative (USDANIFA-OREI) Grant \#2017-51300-268090.Data availabilitySurvey and interview data are both available. Survey respondents are to be kept anonymous unless they opted in. Interview recordings are available but may be redacted to remove confidential business information.

\section{Compliance with ethical standards}

Conflicts of interest The authors declare that they have no conflicts of interest.

Ethics approval The survey and interviews were granted waivers by the Oregon State University Institutional Review Board (Study \#8925).

Consent to participate All survey respondents and interviewees voluntarily consented to participate.

Open Access This article is licensed under a Creative Commons Attribution 4.0 International License, which permits use, sharing, adaptation, distribution and reproduction in any medium or format, as long as you give appropriate credit to the original author(s) and the source, provide a link to the Creative Commons licence, and indicate if changes were made. The images or other third party material in this article are included in the article's Creative Commons licence, unless indicated otherwise in a credit line to the material. If material is not included in the article's Creative Commons licence and your intended use is not permitted by statutory regulation or exceeds the permitted use, you will need to obtain permission directly from the copyright holder. To view a copy of this licence, visit http://creativecommons.org/licenses/by/4.0/.

\section{References}

Anderson RL (2010) A rotation design to reduce weed density in organic farming. Renewable Agric Food Syst 25:189-195

Baker BP, Mohler CL (2014) Weed management by upstate New York organic farmers: strategies, techniques and research priorities. Renewable Agric Food Syst FirstView:1-10. https://doi.org/10.1017/S1742170514000192

Baker BP, Meints BM, Hayes PM (2019) Improving barley for organic producers: what do organic producers want? Oregon State University, Corvallis

Canadian Grain Commission (2006) Test weight conversion chart: hulless barley. Winnipeg, MB

Dillman DA, Smyth JD, Christian LM (2014) Internet, phone, mail, and mixed-mode surveys: the tailored design method. Wiley, New York
Downs H, Hansen R (1998) Estimating farm fuel requirements. Colorado State University, Ft Collins

Drinkwater L (1999) Using plant species composition to restore soil quality and ecosystem function. In: Olesen JE, Eltun R, Gooding $\mathrm{MJ}$, et al. (eds) Designing and testing crop rotations for organic farming. Proceedings from an international workshop. Danish Research Centre for Organic Farming, Tjele, ADK

Grisso RD, Perumpral JV, Vaughan DH et al (2010) Predicting tractor diesel fuel consumption. Virginia Cooperative Extension, Blacksburg

Lampkin, Nicolas (1990) Organic farming. Farming Press ; Distributed in North America by Diamond Farm Enterprises, Ipswich, U.K.; Alexandria Bay, NY, USA

Lazor J (2013) The organic grain grower: small-scale, holistic grain production for the home and market producer. Chelsea Green, White River Junction

McBride W, Greene C, Foreman L, Ali M (2015) The profit potential of certified organic field crop production. USDA Economic Research Service, Washington, DC

Meints B, Hayes PM (2019) Breeding naked barley for food, feed, and malt. Plant Breed Rev 43:95-119

Microsoft (2016) MS Excel 365. Microsoft, Redmond

Mohler CL, Johnson SE (2009) Crop rotation on organic farms: a planning manual, Natural Resource, Agriculture, and Engineering Service (NRAES) Cooperative Extension, Ithaca

Painter K (2011) The costs of owning and operating farm machinery in the Pacific Northwest 2011. University of Idaho, Moscow

Qualtrics (2018) Qualtrics survey software. Qualtrics, Provo

Ryan MR, Mirsky SB, Mortensen DA, Teasdale JR, Curran WS (2011) Potential synergistic effects of cereal rye biomass and soybean planting density on weed suppression. Weed Sci 59: 238-246

SAS (2018) SAS University edition. SAS Institute, Cary

Teasdale JR, Coffman CB, Mangum RW (2007) Potential long-term benefits of no-tillage and organic cropping systems for grain production and soil improvement. Agron J 99:1297-1305

USDA / AMS / NOP (2019) USDA Organic Integrity Database. https://organic.ams.usda.gov/integrity/

USDA / GIPSA (1997) United States standards for barley. US Department of Agriculture grain inspection. Packers and Stockyard Administration, Washington, DC

USDA / NASS (2017) 2016 Certified Organic Survey. USDA / NASS, Washington DC

USDA / NASS (2019) Census of agriculture 2017. US Department of Agriculture, National Agricultural Statistical Service, Washington, DC

USDA NASS (2019) Surveys: cash rents by county. USDA National Agricultural Statistical Service, Washington, DC

Wiersma J, Moncada K, Huerd S (2010) Small grains. In: Moncada KM, Sheaffer CC (eds) Risk management guide for organic producers. University of Minnesota, St Paul, pp 195-213

Wijnands F (1999) Crop rotation in organic farming: theory and practice. In: Designing and testing crop rotations for organic farming. Proceedings from an international workshop. Danish Research Centre for Organic Farming, pp 21-35

Publisher's note Springer Nature remains neutral with regard to jurisdictional claims in published maps and institutional affiliations. 